\title{
Mercury in Tissues of Red Fox as Indicator of Environmental Pollution
}

\author{
Khabarova L.S. \\ Ecological-Analytical Laboratory of Biology Department \\ Cherepovets State University \\ Cherepovets, Russia \\ khabarovals@yandex.ru \\ Poddubnaya N.Ya. \\ Ecological-Analytical Laboratory of Biology Department \\ Cherepovets State University \\ Cherepovets, Russia \\ poddoubnaia@mail.ru
}

Selezneva A.P.

Biology and Human Health Faculty

Cherepovets State University

Cherepovets, Russia

ya.alina-selezneva99@yandex.ru

\author{
Ivanova E.S. \\ Ecological-Analytical Laboratory of Biology Department \\ Cherepovets State University \\ Cherepovets, Russia \\ stepinaelena@yandex.ru
}

Andreeva A.V.

Biology and Human Health Faculty

Cherepovets State University

Cherepovets, Russia

Alla.Andreeva7519@gmail.com

\author{
Feneva D.M. \\ School of education and psychology \\ Cherepovets State University \\ Cherepovets, Russia \\ fenyovadasha@yandex.ru
}

\begin{abstract}
Twenty-three red foxes (Vulpes vulpes L.) were tested for the presence of mercury in their internal organs. These animals were captured in the Vologda region (Northwest Russia) within 2009 and 2018. The animal's liver, kidneys, muscles, brain, spleen, chyme and intestinal wall were tested. The concentrations level ranged between $0.001 \mathrm{mg} / \mathrm{kg}$ of wet mass in the chyme and the brain - up to $0.713 \mathrm{mg} / \mathrm{kg}$ of wet mass in kidneys. There is a strong correlation between the concentrations of mercury in separate pairs of tissues of a red fox. The ratio of concentrations of mercury between the tissues of the red fox was discovered: the concentration of mercury in the brain was 2 to 18 times lower than in other tissues.
\end{abstract}

Keywords - mercury, red fox, tissues

\section{INTRODUCTION}

Russia releases around 4\% of the world's anthropogenic mercury emissions $[1,2]$. The main anthropogenic sources of mercury are metallurgy, combustion of natural organic fuel and solid domestic waste [2]. In the Vologda region there are areas with a varying degree of anthropogenic pollution: the territory of a large metallurgical complex and a specially protected natural area. Recent studies over the last decades show that the amount of mercury in organs and tissues of predators from the Canidae family provides important evidence of mercury contamination in these ecosystems [3]. The red fox is a native species of canids, widespread throughout the region [6]. The mercury levels registered in the organs of red foxes in previous studies varied greatly: the minimal average concentration of the metal in the organs was identified in organs of the foxes caught in suburban and rural areas of Croatia $(0.009 \mathrm{mg} / \mathrm{kg}$ of wet mass in the liver, and
$0.004 \mathrm{mg} / \mathrm{kg}$ of wet mass in its muscles) [4]; the highest average concentration was registered among the foxes from Canada $(0.38 \mathrm{mg} / \mathrm{kg}$ of dry mass in the liver, $0.11 \mathrm{mg} / \mathrm{kg}$ of dry mass in its muscles) [5]. Earlier in the Vologda region high levels of mercury were detected in muscles of fish from the local lakes [7]. Thus, the purpose of this study is to study the concentration of mercury in the tissues of red foxes from areas with different levels of industrial development.

\section{METHODS AND MATERIALS}

The Vologda region lies in the area of 145.7 thousand square kilometers. The length of the region from the west to the east is $650 \mathrm{~km}$ and $380 \mathrm{~km}$ from the north to the south. [6].

The study was carried out from 2015 to 2018 on the territory of 3 administrative units of the Vologda region (Fig. 1): Verkhovazhsky district (1) $-288 \mathrm{~km}$ distant from industrial areas, Kirillovsky district (2) - located in a specially protected natural area, Cherepovetsky district (3) - an area of a large metallurgical complex.

The bodies of the studied animals were received from hunters of regional hunting farms and associations that have hunting licenses. Some parts of the foxes' carcasses were not in sufficient shape to test and thus this did not allow us to select all the necessary tissues for the analysis, so the number of tissue samples varies. Weight (without fur), body length, foot length, and tail length were measured for each animal. Samples of various animal tissues were taken, placed into plastic bags, frozen and stored at a temperature of $-4^{\circ} \mathrm{C}$ to - 
$16^{\circ} \mathrm{C}$. The metal concentration was determined by the atomic absorption of cold steam without preliminary preparation, done with the help of the mercury analyzer RA-915M with the prefix PYRO (sensitivity of the device is $0.001 \mathrm{mg} / \mathrm{kg}$ ). Samples of animal tissues weighing 10-100 $\mathrm{mg}$ were introduced into the thermolysis cell to determine the total mercury concentration. The samples were burned at a temperature of $300^{\circ} \mathrm{C}$ for 1-3 minutes. The measurement accuracy was controlled by using certified biological material DOLT-5 and DORM-4 (Institute of environmental chemistry, Ottawa, Canada).

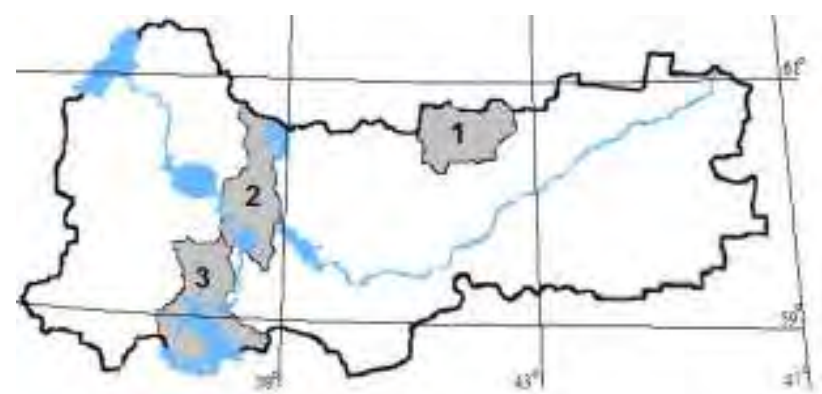

Fig. 1. Study areas: Verkhovazhsky district (1) - $288 \mathrm{~km}$ distant from industrial areas, Kirillovsky district (2) - located in a specially protected natural area, Cherepovetsky district (3) - an area near a large metallurgical complex

The amount of mercury was measured in the liver, kidney, muscle, brain, spleen and wall of the intestine, and the chyme of the red fox. The total number of the analyzed material amounted to 102 samples taken from 23 foxes.

The results of the mercury concentrations measurement in tissues were presented in the form of arithmetic mean, geometric mean with a standard deviation, error of mean, median, minimum and maximum values presented in $\mathrm{mg} / \mathrm{kg}$ of wet mass. The findings were statistically processed: the significance of differences in mercury concentrations was estimated by the nonparametric method using the criterion of Kruskal-Wallis [8]. Correlation between the amount of the metal in different pairs of animal organs was determined using nonparametric Spearman coefficient ( $r s, p \leq 0.05)$ [9].

\section{RESULTS}

The mercury concentration in the tissues of the red fox varies widely - from $0.001 \mathrm{mg} / \mathrm{kg}$ of wet mass in the brain to $0.713 \mathrm{mg} / \mathrm{kg}$ of wet mass in the kidneys (Table II). The concentration of the metal for the studied species decreases in the row: kidneys $(\mathrm{X} 18)>$ liver $(\mathrm{X} 9)>$ muscles $(\mathrm{x} 4)>$ spleen $(\mathrm{X} 3)>$ intestinal wall $(\mathrm{x} 2)>$ thymus $(\mathrm{x} 2)>$ brain $(\mathrm{x} 1)$ (Table 1, Fig. 2).

A strong correlation of mercury concentration in the several pairs of the studied tissues of the red fox was revealed: (rs $=0.56-0.95, \mathrm{p} \leq 0.05, \mathrm{n}=7-18)$ (Table II).

The highest average mercury concentration in all the studied tissues of red fox with the exception of the brain and the gut wall was in animal bodies from Cherepovetsky district (3), which is below the concentration in animal bodies from
Kirillovsky district (2). The minimal concentration was in animal bodies from Verkhovazhsky district (1) (Table III). The established differences were not significant (Fig. 2-6).

TABLE I. THE CONCENTRATION OF MERCURY IN THE TISSUES OF THE RED FOX (MG/KG WET WEIGHT)

\begin{tabular}{|c|c|c|c|c|c|c|c|c|}
\hline & $\mathbf{N}$ & $\mathbf{A M}$ & Median & GM & SD & $\min$ & $\max$ & KW \\
\hline kidney & 14 & 0.305 & 0.225 & 0.240 & 0.210 & 0.067 & 0.713 & $\mathrm{c}$ \\
\hline liver & 14 & 0.176 & 0.125 & 0.123 & 0.164 & 0.022 & 0.640 & $\mathrm{bc}$ \\
\hline spleen & 12 & 0.083 & 0.035 & 0.047 & 0.093 & 0.010 & 0.270 & $a b c$ \\
\hline muscles & 23 & 0.066 & 0.049 & 0.044 & 0.070 & 0.008 & 0.320 & $a b$ \\
\hline $\begin{array}{c}\text { intestinal } \\
\text { wall }\end{array}$ & 9 & 0.044 & 0.040 & 0.029 & 0.037 & 0.005 & 0.115 & $a b$ \\
\hline chyme & 9 & 0.023 & 0.030 & 0.015 & 0.015 & 0.001 & 0.043 & $\mathrm{a}$ \\
\hline brain & 21 & 0.031 & 0.013 & 0.014 & 0.054 & 0.001 & 0.252 & $\mathrm{a}$ \\
\hline
\end{tabular}

a. Note. $\mathrm{N}$ - selection; $\mathrm{AM}$ - arithmetic average; GM - geometric mean; $\mathrm{SD}$ - standard deviation; KW Kruskal-Wallis test ( $\mathrm{a}, \mathrm{b}, \mathrm{c}-$ values validly differ in the organs of red fox from different region (in the column) at the level of significance $\mathrm{p}<0.05$ ).

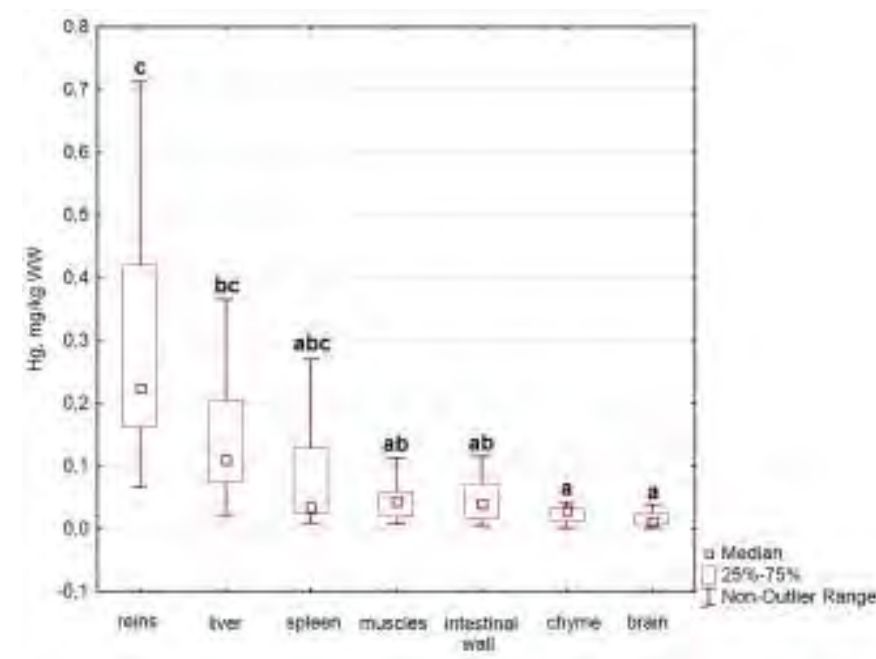

Fig. 2. The concentration of mercury in the tissues of the red fox

High concentration of mercury is typical for the kidneys and liver. Medium levels are typical for its spleen, muscles, intestine wall, and the minimal concentrations are typical for chyme and brain. The mercury level in the kidneys was significantly higher than in muscles, or than in the wall of the intestine, or for the chyme and the brain, and the concentration of metals in the liver was significantly higher than in the chyme and the brain. In most of the previous studies, the maximum mercury concentration was detected in the liver and the kidneys of mammals, which organs have the function of detoxifying the pollutant [10]. 
TABLE II.

CORRELATION OF MERCURY CONTENT IN RED FOX TISSUES

\begin{tabular}{|c|c|c|c|c|c|c|c|}
\hline & kidney & liver & spleen & $\begin{array}{c}\text { muscle } \\
\mathbf{s}\end{array}$ & $\begin{array}{c}\text { intesti } \\
\text { nal } \\
\text { wall }\end{array}$ & chyme & brain \\
\hline 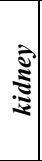 & & $\begin{array}{l}\text { rs } \\
=0.91 \\
p=0.00 \\
(13)\end{array}$ & $\begin{array}{l}\text { rs } \\
=0.86 \\
\mathrm{p}=0.00 \\
(12)\end{array}$ & $\begin{array}{l}\text { rs } \\
=0.66 \\
p=0.03 \\
(11)\end{array}$ & $\begin{array}{l}\text { rs } \\
=0.95 \\
\mathrm{p}=0.00 \\
(9)\end{array}$ & $\begin{array}{l}\text { rs } \\
=0.81 \\
\mathrm{p}=0.01 \\
(9)\end{array}$ & $\begin{array}{l}\text { rs } \\
=0.44 \\
\mathrm{p}=0.1 \\
5 \\
(12)\end{array}$ \\
\hline ڤે & $\begin{array}{l}\mathrm{rs}=0.91 \\
\mathrm{p}=0.00 \\
(13)\end{array}$ & & $\begin{array}{l}\text { rs } \\
=0.88 \\
\mathrm{p}=0.00 \\
(11)\end{array}$ & $\begin{array}{l}\text { rs } \\
=0.68 \\
p=0.02 \\
(11)\end{array}$ & $\begin{array}{l}\text { rs } \\
=0.93 \\
\mathrm{p}=0.00 \\
(9)\end{array}$ & $\begin{array}{l}\text { rs } \\
=0.78 \\
p=0.01 \\
(9)\end{array}$ & $\begin{array}{l}\text { rs } \\
=0.53 \\
\mathrm{p}=0.0 \\
8 \\
(12)\end{array}$ \\
\hline ปั้ & $\begin{array}{l}\mathrm{rs}=0.86 \\
\mathrm{p}=0.00 \\
(12)\end{array}$ & $\begin{array}{l}\text { rs } \\
=0.88 \\
\mathrm{p}=0.00 \\
(11)\end{array}$ & & $\begin{array}{l}\text { rs } \\
=0.57 \\
p=0.11 \\
(9)\end{array}$ & $\begin{array}{l}\text { rs } \\
=0.88 \\
\mathrm{p}=0.00 \\
(9)\end{array}$ & $\begin{array}{l}\text { rs } \\
=0.73 \\
p=0.03 \\
(9)\end{array}$ & $\begin{array}{l}\text { rs } \\
=0.54 \\
\mathrm{p}=0.1 \\
1 \\
(10)\end{array}$ \\
\hline 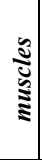 & $\begin{array}{l}\mathrm{rs}=0.66 \\
\mathrm{p}=0.03 \\
(11)\end{array}$ & $\begin{array}{l}\text { rs } \\
=0.68 \\
p=0.02 \\
(11)\end{array}$ & $\begin{array}{l}\text { rs } \\
=0.57 \\
\mathrm{p}=0.11 \\
(9)\end{array}$ & & $\begin{array}{l}\text { rs } \\
=0.89 \\
p=0.01 \\
(7)\end{array}$ & $\begin{array}{l}\text { rs } \\
=0.66 \\
p=0.08 \\
(8)\end{array}$ & $\begin{array}{l}\text { rs } \\
=0.56 \\
\mathrm{p}=0.0 \\
2 \\
(18)\end{array}$ \\
\hline 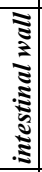 & $\begin{array}{l}\text { rs }=0.95 \\
p=0.00 \\
(9)\end{array}$ & $\begin{array}{l}\text { rs } \\
=0.93 \\
\mathrm{p}=0.00 \\
(9)\end{array}$ & $\begin{array}{l}\text { rs } \\
=0.88 \\
\mathrm{p}=0.00 \\
\text { (9) }\end{array}$ & $\begin{array}{l}\text { rs } \\
=0.89 \\
p=0.01 \\
(7)\end{array}$ & & $\begin{array}{l}\text { rs } \\
=0.74 \\
p=0.04 \\
(8)\end{array}$ & $\begin{array}{l}\mathrm{rs} \\
=0.64 \\
\mathrm{p}=0.0 \\
9 \\
(8) \\
\end{array}$ \\
\hline 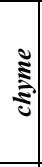 & $\begin{array}{l}\mathrm{rs}=0.81 \\
\mathrm{p}=0.01 \\
(9)\end{array}$ & $\begin{array}{l}\text { rs } \\
=0.78 \\
p=0.01 \\
(9)\end{array}$ & $\begin{array}{l}\text { rs } \\
=0.73 \\
\mathrm{p}=0.03 \\
\text { (9) }\end{array}$ & $\begin{array}{l}\text { rs } \\
=0.66 \\
p=0.08 \\
(8)\end{array}$ & $\begin{array}{l}\text { rs } \\
=0.74 \\
\mathrm{p}=0.04 \\
(8)\end{array}$ & & $\begin{array}{l}\text { rs } \\
=0.18 \\
\mathrm{p}=0.6 \\
7 \\
(8) \\
\end{array}$ \\
\hline 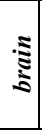 & $\begin{array}{l}\mathrm{rs}=0.44 \\
\mathrm{p}=0.15 \\
(12)\end{array}$ & $\begin{array}{l}\text { rs } \\
=0.53 \\
\mathrm{p}=0.08 \\
(12)\end{array}$ & $\begin{array}{l}\text { rs } \\
=0.54 \\
\mathrm{p}=0.11 \\
(10)\end{array}$ & $\begin{array}{l}\text { rs } \\
=0.56 \\
p=0.02 \\
(18)\end{array}$ & $\begin{array}{l}\text { rs } \\
=0.64 \\
\mathrm{p}=0.09 \\
(8)\end{array}$ & $\begin{array}{l}\text { rs } \\
=0.18 \\
p=0.67 \\
(8)\end{array}$ & \\
\hline
\end{tabular}

b. Note. Statistically significant correlation relations (Spearman's coefficient $-\mathrm{rs}$ ) are highlighted in bold.

High levels of metals in the liver of the animals can be used as an indicator of environmental pollution, since the concentration of the metal in the body reflects the degree of influence of mercury on ecosystems. To estimate the impact of mercury on mammals, it is not enough to detect the concentration of the metal in the liver and the kidneys; therefore, much of the mercury in these tissues often presents in a less toxic, inorganic form. The proportion of methylmercury in the liver and kidneys is lower than in the brain and muscles [11]. In this study, it was found that the amount of metal in the mammalian brain was 9 times less than in the liver. The authors attributed this to different biochemical composition, metabolism and various functions of tissues [14].

Reliable statistically significant correlations between the concentration of mercury in all tissue pairs (excluding pairs: muscle-spleen, muscle-chyme, brain-kidney, brain-liver, brain-spleen, brain-intestine, brain-chyme) of the red fox of the Vologda region is comparable to the previously estimated ratio to organs (liver-muscle ( $\mathrm{rs}=0.74, \mathrm{p} \leq 0.01)$, kidney-liver $(\mathrm{rS}=0.60, \mathrm{p} \leq 0.01)$, measured in the red fox from Poland [12].

The level of mercury in the tissues of the fox from the area around a large metallurgical complex (Cherepovetsky district
- 3) is comparable to the concentration of mercury in the tissues of the fox from a specially protected natural area (Kirillovsky district -2 ) and an area significantly distant from industrial complexes (Verkhovazhsky district -1).

TABLE III. THE CONCENTRATION OF MERCURY IN THE TISSUES OF RED FOX IN DIFFERENT AREAS OF VOLOGDA REGION (MG/KG WET WEIGHT)

\begin{tabular}{|c|c|c|c|c|c|c|c|c|}
\hline \multicolumn{9}{|c|}{ liver } \\
\hline Area & $N$ & $A M$ & Median & $G M$ & $S D$ & $\min$ & $\max$ & $K W$ \\
\hline 1 & 2 & 0.093 & 0.094 & 0.093 & 0.023 & 0.078 & 0.110 & $\mathrm{a}$ \\
\hline 2 & 5 & 0.107 & 0.094 & 0.085 & 0.069 & 0.022 & 0.204 & $\mathrm{a}$ \\
\hline 3 & 6 & 0.184 & 0.199 & 0.140 & 0.125 & 0.045 & 0.365 & $\mathrm{a}$ \\
\hline \multicolumn{9}{|c|}{ kidney } \\
\hline Area & $N$ & $\boldsymbol{A M}$ & Median & $G M$ & $S D$ & $\min$ & $\max$ & $K W$ \\
\hline 1 & 2 & 0.196 & 0.196 & 0.193 & 0.048 & 0.162 & 0.230 & $\mathrm{a}$ \\
\hline 2 & 5 & 0.245 & 0.220 & 0.215 & 0.127 & 0.087 & 0.411 & $\mathrm{a}$ \\
\hline 3 & 7 & 0.379 & 0.420 & 0.277 & 0.266 & 0.067 & 0.713 & $\mathrm{a}$ \\
\hline \multicolumn{9}{|c|}{ spleen } \\
\hline Area & $N$ & $A M$ & Median & $G M$ & $S D$ & $\min$ & $\max$ & $K W$ \\
\hline 1 & 2 & 0.025 & 0.025 & 0.025 & 0.007 & 0.020 & 0.030 & $\mathrm{a}$ \\
\hline 2 & 5 & 0.031 & 0.031 & 0.029 & 0.011 & 0.013 & 0.040 & $\mathrm{a}$ \\
\hline 3 & 5 & 0.158 & 0.163 & 0.101 & 0.108 & 0.010 & 0.270 & $\mathrm{a}$ \\
\hline \multicolumn{9}{|c|}{ muscles } \\
\hline Area & $N$ & $A M$ & Median & $G M$ & $S D$ & $\min$ & $\max$ & $K W$ \\
\hline 1 & 7 & 0.041 & 0.050 & 0.036 & 0.021 & 0.017 & 0.070 & $\mathrm{a}$ \\
\hline 2 & 6 & 0.044 & 0.043 & 0.036 & 0.026 & 0.012 & 0.083 & $\mathrm{a}$ \\
\hline 3 & 7 & 0.048 & 0.028 & 0.034 & 0.042 & 0.008 & 0.113 & $\mathrm{a}$ \\
\hline \multicolumn{9}{|c|}{ brain } \\
\hline Area & $N$ & $A M$ & Median & $G M$ & $S D$ & $\min$ & $\max$ & $K W$ \\
\hline 1 & 6 & 0.018 & 0.020 & 0.017 & 0.006 & 0.010 & 0.026 & $\mathrm{a}$ \\
\hline 2 & 5 & 0.007 & 0.006 & 0.005 & 0.004 & 0.001 & 0.012 & $\mathrm{a}$ \\
\hline 3 & 8 & 0.021 & 0.019 & 0.013 & 0.016 & 0.001 & 0.039 & $\mathrm{a}$ \\
\hline \multicolumn{9}{|c|}{ chyme } \\
\hline Area & $N$ & $A M$ & Median & $G M$ & $S D$ & $\min$ & $\max$ & $K W$ \\
\hline 1 & 1 & 0.001 & 0.001 & 0.001 & 0.000 & 0.001 & 0.001 & $\mathrm{a}$ \\
\hline 2 & 5 & 0.025 & 0.030 & 0.022 & 0.013 & 0.012 & 0.043 & $\mathrm{a}$ \\
\hline 3 & 3 & 0.026 & 0.032 & 0.021 & 0.017 & 0.007 & 0.040 & $\mathrm{a}$ \\
\hline \multicolumn{9}{|c|}{ intestinal wall } \\
\hline Area & $N$ & $A M$ & Median & $G M$ & $S D$ & $\min$ & $\max$ & $K W$ \\
\hline 1 & 1 & 0.027 & 0.027 & 0.027 & 0.000 & 0.027 & 0.027 & $\mathrm{a}$ \\
\hline 2 & 4 & 0.026 & 0.029 & 0.019 & 0.018 & 0.005 & 0.041 & $\mathrm{a}$ \\
\hline 3 & 4 & 0.067 & 0.073 & 0.046 & 0.045 & 0.007 & 0.115 & $\mathrm{a}$ \\
\hline
\end{tabular}

c. Note. $\mathrm{N}$ - selection; AM - arithmetic average; GM - geometric mean; SD - standard deviation; KW Kruskal-Wallis test $(\mathrm{a}, \mathrm{b}, \mathrm{c}-$ values validly differ in the organs of red fox from different regions (in the column), at the level of significance $\mathrm{p}<0.05$ ).

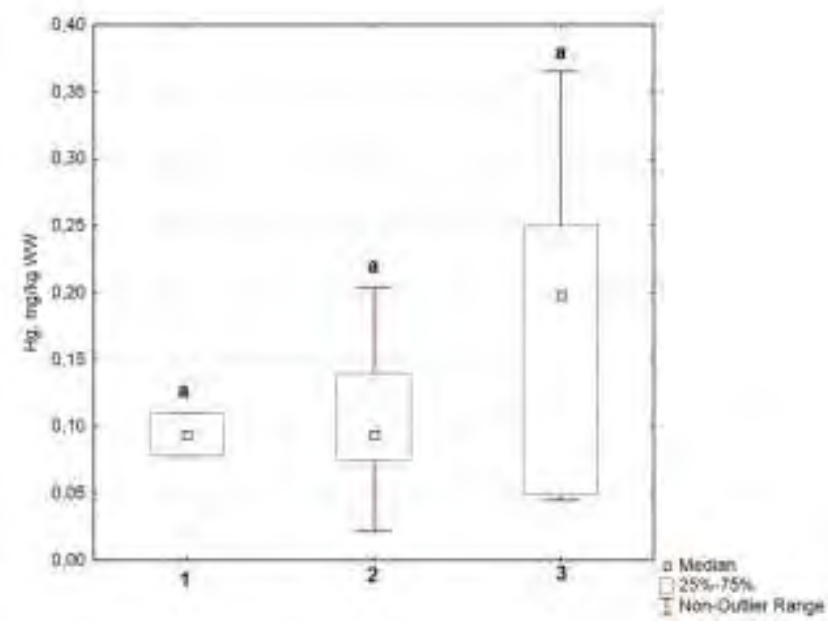

Fig. 3. The concentration of mercury in the liver of the red fox caught in different areas of the Vologda region 


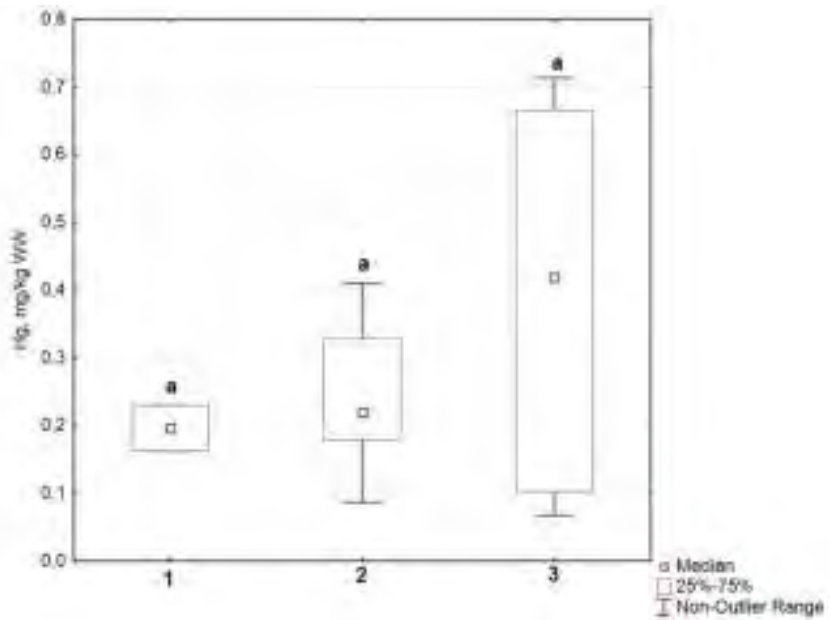

Fig. 4. The concentration of mercury in the kidneys of the red fox caught in different areas of the Vologda region

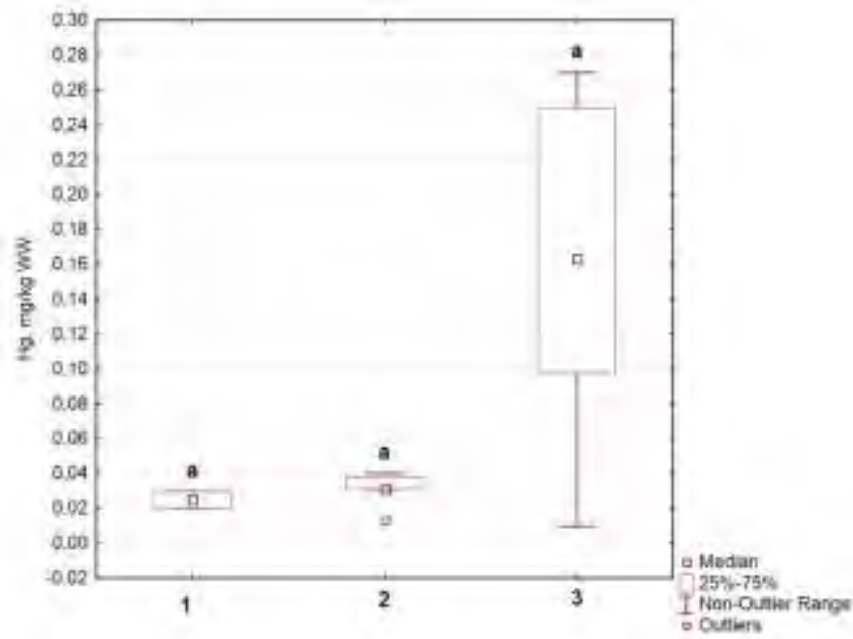

Fig. 5. The concentration of mercury in the spleen of the red fox caught in different areas of the Vologda region

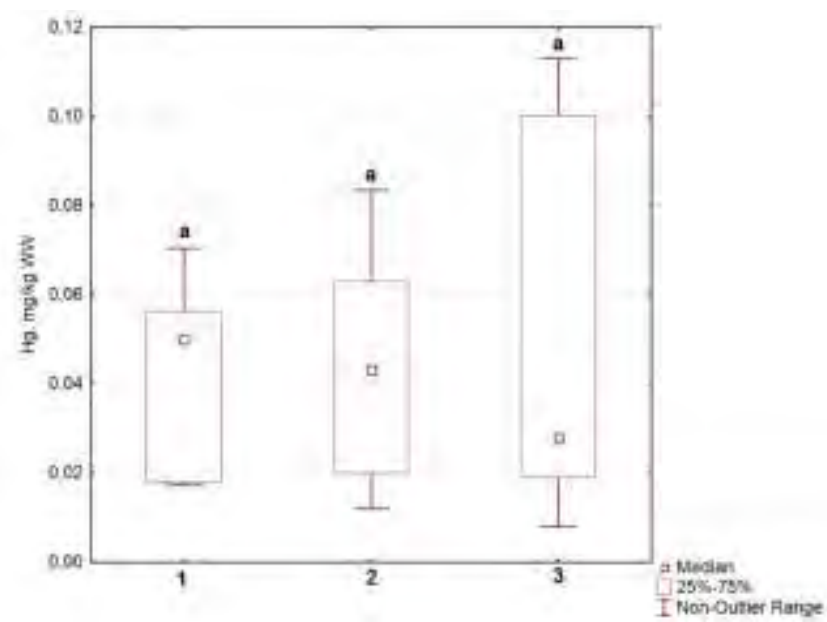

Fig. 6. The concentration of mercury in the muscles of the red fox caught in different areas of the Vologda region

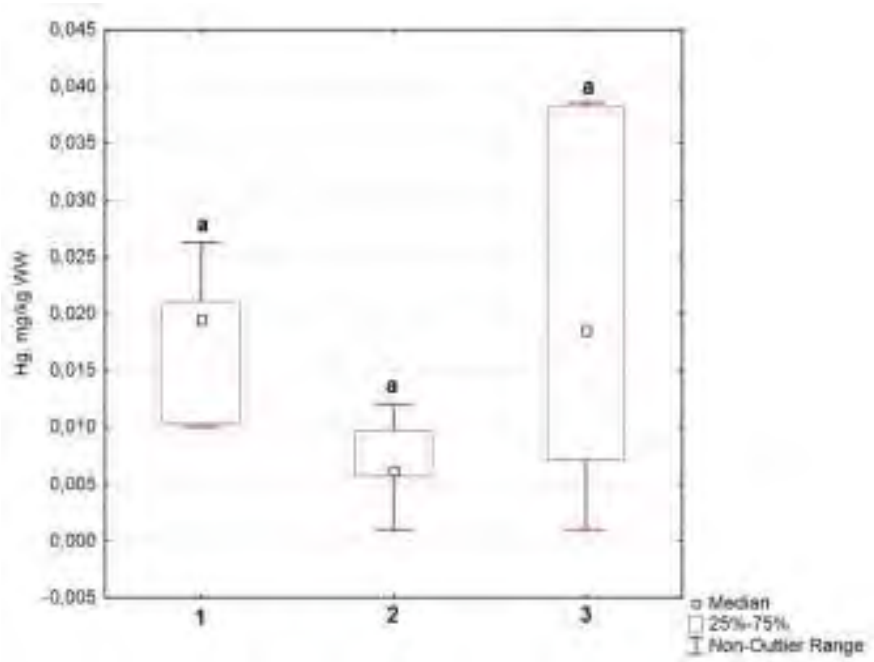

Fig. 7. The concentration of mercury in the brain of the red fox caught in different areas of the Vologda region

The concentration of mercury in the muscles, liver and brain of foxes from the industrial region was confirmed by the data on the content of mercury in red foxes, previously studied in this area [13]. The average concentration of mercury in the muscles of the red fox from the Vologda region is 2 times higher than in the muscles of the fox from suburban areas of Croatia [4] and 3 times lower than in the muscles of the fox from regions contaminated with heavy metals in Spain, where for a long time there was a mining activity [15]. The concentration of mercury in the fox liver in the studied area is 3 times lower than in the liver of foxes in Italy [17] and 2-3 times higher than in the liver of foxes in Canada [5]. The concentration of mercury in the kidneys of the fox of the Vologda region is 5 times lower than in the kidneys of the fox from the north-west of Poland [16].

\section{CONCLUSION}

The concentration of metal in the kidneys is significantly higher than in muscles, intestinal walls, chymus and brain, and the concentration of the metal in the liver is significantly higher than in the chymus and brain. Reliable statistically significant correlations are set between mercury concentrations in all pairs of tissues (except for pairs: musclesspleen, muscles-chyme, brain-kidneys, brain-liver, brainspleen, brain-intestine, brain-chyme) of the red fox of the Vologda region. There were no statistically significant differences between mercury concentrations in all tissues of the red fox caught from the regions of the Vologda region with different levels of industrial development.

\section{Acknowledgment}

The reported study was funded by RFBR according to research project № 18-34-00569

\section{References}

[1] S.J. Wilson, F. Steenhuisen, J.M. Pacyna, E.G. Pacyna, "Mapping the spatial distribution of global anthropogenic mercury atmospheric 
emission inventories", Atmospheric Environment, vol. 40, pp. 46214632, August 2006.

[2] AMAP, UNEP, Technical background report to the global atmospheric mercury assessment. Arctic Monitoring and Assessment Programme, UNEP Chemicals Branch, Geneva, 2008, pp. 1-159.

[3] J. Munthe, S. Hellsten, T. Zetterberg, "Mobilization of mercury and methylmercury from forest soils after a severe storm-fell event", Ambio, vol. 36, pp. 111-113, February 2007.

[4] N. Bilandzic, D. Dezdek, M. Sedak, M. Dokic, B. Solomun, I. Varenina, Z. Knezevic, A. Slavica, "Concentrations of trace elements Bull Environ Contam Toxicol 123 in tissues of red fox (Vulpes vulpes) and stone marten (Martes foina) from suburban and rural areas in Croatia," Bulletin of Environmental Contamination and Toxicology, vol. 85, pp. 486-491, November 2010

[5] L. Champoux, J. Rodrigue, B. Braune, D. Leclair, "Contaminants in Northern Québec wildlife", Department of Indian Affairs and Northern Development, Ottawa, 1999, pp. 109-116.

[6] G.A. Vorobev, Yu.N. Belova, N.L. Bolotova, M.Ya. Borisov, "Priroda Vologodskoi oblasti”, Ed. house Vologzhanin, Vologda, 2007, p. 434.

[7] I.K. Stepanova, V.T. Komov, "Mercury accumulation in fish from water bodies of the Vologodskaya Oblast", Russian Journal of Ecology, vol. 28, pp. 260-265, January 1997.

[8] W.H. Kruskal, W.A. Wallis, "Use of ranks in one-criterion variance analysis", Journal of the American Statistical Association, vol. 47, pp. 583-621, December 1952.

[9] R.R. Socal, F.J. Rolf, "The principals and practice of Statistics in biological research", W.H. Freeman and Company, New York, 1995, p. 887.

[10] D. Cristol, R.L. Brasso, A.M. Condon, R.E. Fovargue, S.L. Friedman, K.K. Hallinger, A.P. Manroe, A.E. White, "The movement of aquatic mercury through terrestrial food webs", Science, vol. 320, pp. 335, April 2008.

[11] S.M. Strom, "Total mercury and methylmercury residues in river otters (Lutra canadensis) from Wisconsin", Archives of Environmental Contamination and Toxicology, vol. 54, pp. 546-554, April 2008.

[12] E. Kalisinska, M. Palczewska-Komsa, "Teeth of the red fox Vulpes vulpes (L., 1758) as a bioindicator in studieson fluoride pollution", Acta Theriologica, vol. 56, pp. 343-351, October 2011.

[13] V.T. Komov, E.S. Ivanova, V.A. Gremyachikh, N.Y. Poddubnaya, "Mercury Content in Organs and Tissues of Indigenous (Vulpes vulpes L.) and Invasive (Nyctereutes procyonoides Gray) Species of Canids from Areas Near Cherepovets (North-Western Industrial Region, Russia)", Bulletin of Environmental Contamination and Toxicology, vol. 97, July 2016.

[14] U. Ulfvarson, "Transportation of mercury in animals", Arbetsmedicinska institutet, Stockholm, 1970.

[15] J. Millán, R. Mateo, M.A. Taggart, J.V. López-Bao, M. Viota, L. Monsalve, P.R. Camareo, E. Blázquez, B. Jiménez, "Levels of heavy metals and metalloids in critically endangered Iberian lynx and other wild carnivores from Southern Spain", Science of the Total Environment, vol. 399, pp. 193-201, July 2008.

[16] E. Kalisinska, P. Lisowski, W. Salicki, T. Kucharska, K. Kavetska, "Mercury in wild terrestrial carnivorous mammals from north-western Poland and unusual fish diet of red fox", Acta Theriologica, vol. 54, pp. 345-356, December 2009.

[17] E. Alleva, N. Francia, N. Pandolfi, A.M. Marinis, F. Chiarotti, D. Santucci, "Organochlorine and heavy-metal contaminants in wild mammals and birds of Urbino-Pesaro Province, Italy: an analytical overview for potential bioindicators", Archives of Environmental Contamination and Toxicology, vol. 51, pp. 123-124, July 2006. 